\title{
Pengaruh Pemberian Ekstrak Etanol Daun Paitan (Titonia diversifolia, H) Terhadap Kadar Gula Darah Mencit (Mus musculus) jantan
}

\author{
Kenti Prahmanti ${ }^{\star}$, Dayu Liandra \\ Akademi Farmasi Bumi Siliwangi, Bandung, 40286 \\ *Email korespondensi: kenti88@.gmail.com \\ (Submit 15/03/2019, Revisi 05/09/2019, Diterima 20/12/2019)
}

\begin{abstract}
Abstrak
Diabetes Melitus merupakan kelainan metabolisme karbohidrat dengan karakteristik hiperglikemia. Diabetes melitus dapat disebabkan oleh kelainan sekresi insulin karena kerusakan sel beta pada pankreas dan juga resistensi insulin. Daun paitan (Tithonia diversifolia, H) mengandung tanin, flavonoid, glikosida, saponin, dan triterpenoid/ steroid. Aktivitas hipoglikemik tanin terjadi melalui peningkatan glikogenesis, sehingga tanaman ini memiliki potensi sebagai antidiabetes. Penelitian ini bertujuan untuk mengetahui pengaruh pemberian ekstrak etanol daun paitan (Tithonia diversifolia, H) terhadap kadar gula darah mencit (Mus musculus) jantan. Daun paitan (Tithonia diversifolia, H) Penelitian dilakukan secara in vivo dengan mengukur toleransi glukosa pada hewan uji mencit mencit (Mus musculus). Sampel yang digunakan adalah mencit jantan yang terbagi ke dalam 6 kelompok perlakuan dan 3 kali pengulangan, yaitu KN (kontrol negatif), KP (Aloxan), P1 (aloxan + dosis $250 \mathrm{mg} / \mathrm{kgBB} / \mathrm{hari}$ ), P2 (aloxan + dosis $500 \mathrm{mg} / \mathrm{kgBB} / \mathrm{hari}$ ), P3 (aloxan + dosis $750 \mathrm{mg} / \mathrm{kgBB} /$ hari) dan P4 (aloxan + metformin $500 \mathrm{mg} / \mathrm{kgBB}$.hari). Analisis data menggunakan one way ANOVA, dilanjutkan dengan uji duncan. Hasil penelitian menunjukkan daun paitan (Tithonia diversifolia, H) memberikan pengaruh positif terhadap penurunan kadar gula darah mencit (Mus musculus) jantan. Pada dosis $500 \mathrm{mg} / \mathrm{kgBB} /$ hari memberikan aktivitas penurunan kadar gula darah lebih baik dibandingkan dengan obat pembanding (metformin) pada $p<$ 0,05 . Daun paitan (Tithonia diversifolia, $\mathrm{H}$ ) memiliki aktivias antidiabetes pada dosis 500 $\mathrm{mg} / \mathrm{kgBB} / \mathrm{hari}$.
\end{abstract}

Kata kunci: Diabetes melitus, daun paitan, tanin, flavonoid

\section{Outline}

- Pendahuluan

- Metode

- Hasil dan Pembahasan

- Kesimpulan

- Daftar Pustaka

\section{Pendahuluan}

Diabetes Melitus (DM) adalah penyakit gangguan metabolisme yang ditandai dengan hiperglikemia kronik $^{1,2}$ dan berhubungan dengan abnormalitas pada metabolisme karbohidrat, lemak dan protein ${ }^{3,4}$. Hiperglikemia terjadi karena adanya kelainan sekresi insulin, resistensi insuin atau keduanya ${ }^{3,5}$. 
Prevalensi penderita diabetes melitus di Indonesia mencapai 8,6 \% dari total penduduk, menempatkan Indonesia di urutan ke empat setelah India, Cina dan Amerika ${ }^{6}$. IDF (International Diabetes Foundation) memprediksi terjadinya kenaikan jumlah penderita DM dari 9.1 juta pada tahun 2014 menjadi 14.1 juta pada tahun 20307. Hasil riset kesehatan dasar yang dilakukan pada tahun 2013 menunjukkan besarnya jumlah penderita DM di Indonesia yaitu sekitar 12.191.564 orang ${ }^{8}$.

Berdasarkan etiologinya, DM dibagi menjadi 2, yaitu diabetes melitus tipe 1 (DMT1) dan diabetes meilitus tipe 2 (DMT2). Pada DMT1 sel $\beta$-pankreas gagal mensekresikan insulin atau insulin yang dihasilkan sedikit 1,4,9,10. Rusaknya sel $\beta$-pankreas berkaitan dengan kerja ROS (Reactive Oxygen Species) secara simultan yang menyebabkan terjadinya peningkatan kalsium sitosol ${ }^{11}$. Sedangkan pada DMT2 dikarakterisasi oleh beberapa gangguan seperti gangguan sekresi insulin, resistensi insulin pada otot, hati, dan adipose, sekresi glukagon yang berlebih, serta definisi GLP-14. Penatalaksanaan DM umumnya dimulai dengan pendekatan non farmakologi seperti diet dan perubahan gaya hidup ${ }^{1,6}$. Pendekatan farmakologi dilakukan dengan pemberian obat antidiabetik oral $(\mathrm{OAD})^{12}$.

Metformin direkomendsikan sebagai OAD lini pertama pada DMT2 ${ }^{13-15}$. Pemberian metformin pada penderita DMT2 mem- berikan sensitivitas pada insulin perifer dan hepatik ${ }^{6,15,16}$. Meskipun pemberian metformin menghasilkan kontrol glukosa darah yang intensif, namun juga mem- berikan efek samping berupa gangguan gastro-intestinal seperti diare, mual, muntah dan perut kembung $6,8,9,16$, Selain menimbulkan faktor resiko berupa efek samping yang tidak diinginkan, pemberian obat antidiabetik oral juga dirasakan mahal. Beban ekonomi penyakit DM di Indonesia diperkirakan meningkat hingga $\$ 1,27$ milyar pada tahun $2020^{17}$.

Adanya efek samping dan biaya yang relatif mahal menyebabkan obat tra- disional menjadi alternatif dalam pe- nanganan DM di Indonesia. Tanaman dengan kandungan senyawa antioksidan tinggi memiliki potensi sebagai antidiabetes yang mampu mencegah terjadinya oksidasi glukosa dalam darah ${ }^{18}$. Salah satu obat tradisional yang digunakan untuk pengobatan DM adalah daun paitan (Tithonia diversifolia, $H$ ), yang merupa- kan spesies tanaman berbunga dari keluarga Asteraceae ${ }^{15}$. Daun paitan memiliki kandungan flavonoid, glikosida, saponin, dan tanin ${ }^{19}$.

Flavonoid dapat mencegah absorbsi gula, menstimulasi pengambilan glukosa pada jaringan perifer, juga dapat bertindak seperti paitan dengan cara mempengaruhi mekanisme insulin signaling ${ }^{6}$. Tanin dapat memacu metabolisme glukosa dan lemak, sehingga timbunan dari kedua sumber kalori ini dapat dihindari. Tanin juga memiliki aktivitas hipoglikemik dengan meningkatkan glikogenesis ${ }^{2}$. Sehingga daun paitan memiliki prospek untuk dikembangkan sebagai obat anti- diabetik oral.

\section{Metode Penelitian}

Penelitian ini merupakan penelitian experimental secara in vitro di laboratorium dengan disain acak lengkap. Penelitian dilakukan di Laboratotium Fitokimia Farmakognosi, Akademi farmasi Bumi Siliwangi pada bulan Mei - Juli 2017.

\section{A. Populasi dan Sampel}

Populasi dan sampel penelitian ini adalah mencit (Mus musculus) dewasa, jantan 
dengan berat bobot 20-35 gram dan sehat, sebanyak 18 ekor, di kelompokan secara acak.

\section{B. Prosedur Penelitian}

1. Tahap Penyiapan Ekstrak

Ekstraksi dilakukan dengan cara maserasi, atau perendaman menggunakan etanol $80 \%$ selama $3 \times 24$ jam. Maserasi digunakan karena tidak menggunakan panas, sehingga kemungkinan rusaknya zat aktif yang terkandung dalam tanaman dapat dihindarkan. Sebanyak $1 \mathrm{~kg}$ simplisia daun paitan direndam dengan etanol 2 liter selama 24 jam, kemudian di saring dan diambil maseratnya. Ampas direndam kembali dengan etanol 2 liter direndam kembali selama 24 jam. Proses dilakukan kembali sebanyak 2 kali. Maserat dikumpulkan dan dikeringkan mengguna- kan rotary evaporator.

\section{Tahap Penyiapan Hewan uji}

Hewan uji (mencit) dewasa dengan berat bobot 20-35 gram dan sehat di kelompokan secara acak. Tiap kelompok terdiri dari tiga ekor mencit, terdiri dari kelompok negatif (KN) hanya mendapatkan makan dan minum tanpa induksi aloxan, kelompok positif (KP) hanya mendapatkan aloxan tanpa ekstrak, kelompok Aloxan + ektstrak dengan dosis $250 \mathrm{mg} / \mathrm{kgBB}$ (P1), Aloxan + ekstrak dengan dosis 500 mg/kgBB (P2), Aloxan + ekstrak dengan dosis 750 mg / kgBB (P3), dan kelompok Aloxan + metformin dosis 500 $\mathrm{mg}$ (P4). Mencit diaklimatisasi selama 7 hari sebelum diberi perlakuan.

\section{Tahap Pengukuran Kadar Gula Darah}

Setelah diaklimatisasi selama 7 hari Mencit diinduksi larutan aloxan $125 \mathrm{mg} / \mathrm{kgBB} / \mathrm{hari}$ selama 14 hari berturut- turut mulai hari ke-8 sampai hari ke-21. Mencit yang sudah mengalami hiperglikemia (kadar gula > $200 \mathrm{mg} / \mathrm{dL}$ ) diberi ekstrak dan metformin sesuai kelompok perlakuan setelah dikonversi sesuai berat badan mencit.

Pada hari ke-7, dilakukan pengambilan cuplikan darah ekor terhadap semua mencit untuk menentukan kadar gula darah. Kadar glukosa darah diukur menggunakn glukometer, Gluko DrTm. Setiap kali pengambilan darah, mencit dipuasakan selama 16 jam. Pengambilan cuplikan darah ekor dilaku-kan lagi pada hari ke 14 dan 21.

\section{Tahap Pengumpulan Data}

Pengumpulan data dilakukan dengan mencatat penurunan kadar gula darah mencit pada semua kelompok perlakuan.

\section{Tahap Analisis Data}

Analisis data dilakukn menggunakan One-way ANOVA untuk mengetahui ada tidaknya pengaruh dari setiap perlakuan yang diberikan. Untuk melihat perlakuan yang paling efektif maka digunakan uji Duncan. Semua proses analisis data dilakukan dengan bantuan SPSS versi 20.

\section{Hasil dan Pembahasan}

Mencit pada semua kelompok d- induksi dengan alloksan sehingga di capai kadar > $200 \mathrm{mg} / \mathrm{dL}$ (hiperglikemia). asil analisis sidik ragam (ANOVA) dan uji duncan menunjukkan rataan kadar gula darah pada kelompok yang diberi aloxan berbeda nyata $(p<0,05)$ dibandingkan dengan kelompok normal dan kelompok yang diberi metformin. 
Pengaruh pemberian metformin $125 \mathrm{mg} / \mathrm{kgBB}$ pada kelompok kontrol positif (KP) dibandingkan terhadap kelompok kontrol negatif $(\mathrm{KN})$ yang hanya diberi aquadest dapat dilihat pada tabel 1 berikut ini. Tabel di bawah ini menunjukkan kadar gula darah mencit hasil induksi aloksan.

Tabel 1. Kadar Gula Darah Mencit Yang Diinduksi Aloxan (mg/dL)

\begin{tabular}{|c|l|c|c|c|c|c|c|}
\hline \multirow{2}{*}{ No } & \multicolumn{1}{|c|}{ Kelompok } & \multicolumn{5}{|c|}{ Kadar Gula Darah (mg/dL) } \\
\hline $\mathbf{1}$ & Kontrol Negatif (KN) & 7 & 2 & 3 & Rerata & STDEV \\
\hline $\mathbf{2}$ & Aloxan $125 \mathrm{mg} / \mathrm{kgBB}(\mathrm{KP})$ & 73 & 64 & 78 & 71,7 & $\mathbf{7 , 0 9}$ \\
\hline $\mathbf{3}$ & Aloxan + Ekstrak 250 mg/kgBB/hari (P1) & 245 & 300 & 267 & 270,7 & 27,68 \\
\hline $\mathbf{4}$ & Aloxan + Ekstrak 500 mg/kgBB/hari (P2) & 398 & 345 & 400 & 381,0 & 31,19 \\
\hline $\mathbf{5}$ & Aloxan + Ekstrak 750 mg/kgBB/hari (P3) & 365 & 388 & 428 & 393,7 & 31,88 \\
\hline $\mathbf{6}$ & Aloxan + Metformin 500 mg/kgBB/hari (P4 & 320 & 368 & 381 & 356,3 & 32,13 \\
\hline
\end{tabular}

Kondisi peningkatan kadar gula darah $>200 \mathrm{mg} / \mathrm{dL}$ dialami oleh mencit kelompok $\mathrm{P} 1$, P2, P3, P4 dan KP. Hal Ini menunjukan, pemberian aloksan dengan dosis 125 $\mathrm{mg} / \mathrm{kgBb} / \mathrm{hari}$ dapat meningkatkan kadar gula darah mencit. Hal ini sejalan dengan penelitian yang dilakukan oleh Nugroho pada tahun 2006. Tikus yang diinduksi aloxan $120 \mathrm{mg} / \mathrm{kgBB}-150 \mathrm{mg} / \mathrm{kgBB}$ demperlihatkan kondisi hiperglikemia ${ }^{9}$.

Aloksan merupakan senyawa hidrofilik yang tidak stabil dan selektif toksik terhadap hati dan ginjal, tetapi dalam dosis tertentu menyebabkan des- truktif selektif pada sel beta pankreas. Pemberian aloksan adalah suatu cara yang cepat untuk menghasilkan kondisi diabetik eksperimental (hiperglikemia) pada hewan percobaan 20.

Aloksan dapat menyebabkan DM tergantung insulin pada binatang tersebut dengan karakteristik mirip dengan diabetes mellitus tipe 1 pada manusia. Meningkatnya kadar glukosa darah mencit karena pemberian aloxan dapat disebabkan karena terbentuknya radikal bebas dan kerusakan permeabilitas membran sel sehingga terjadi kerusakan sel beta pankreas yang berfungsi menghasilkan insulin sehingga kadar gula darah meningkat ${ }^{20}$.

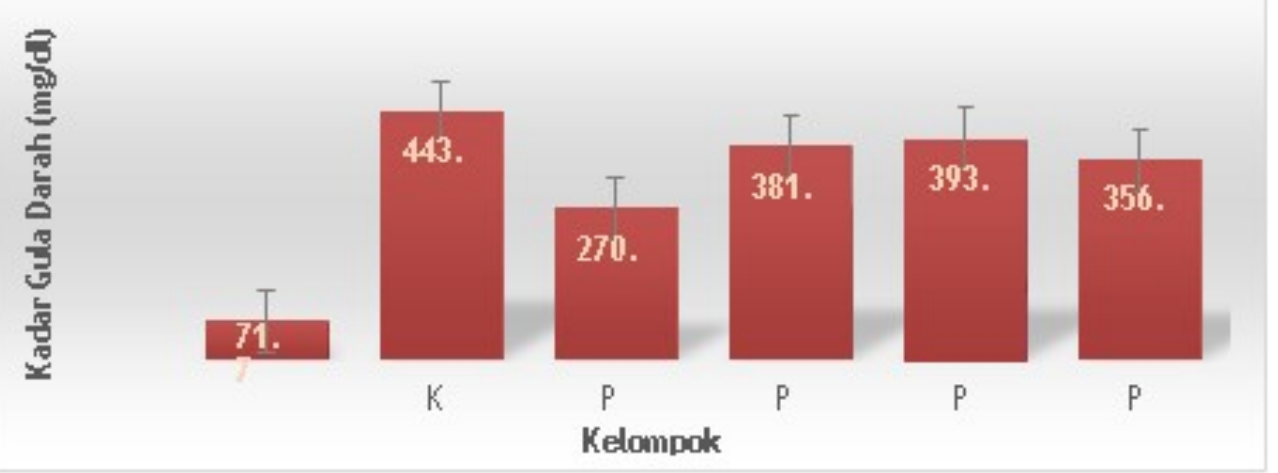

Gambar 1. Pengaruh Induksi Aloksan Terhadap Kadar Gula darah Mencit

Hasil analisis sidik ragam (ANOVA) dan uji duncan menunjukkan adanya pengaruh yang nyata pada pemberian ekstrak daun paitan dan aloxan terhadap kadar gula darah mencit pada masing-masing perlakukan $(\alpha=0.05)$. 
Tabel 2. Pengaruh Pemberian Ekstrak Daun Paitan Terhadap Kadar Gula Darah Mencit

\begin{tabular}{|c|c|c|c|c|c|c|}
\hline \multirow{2}{*}{ No } & \multirow{2}{*}{ Kelompok } & \multicolumn{5}{|c|}{ Kadar Gula Darah (mg/dL) } \\
\hline & & 1 & 2 & 3 & Rerata & Stdev \\
\hline 1 & Kontrol Negatif (KN) & 73 & 64 & 78 & 71,67 & 7,09 \\
\hline$\overline{2}$ & Aloxan 125 mg/kgBB (KP) & 443 & 470 & 416 & 443 & 27 \\
\hline 3 & Aloxan + Ekstrak 250 mg/kgBB/hari (P1) & 185 & 173 & 179 & 179 & 6 \\
\hline 4 & Aloxan + Ekstrak 500 mg/kgBB/hari (P2) & 146 & 138 & 140 & 141,33 & 4,16 \\
\hline 5 & Aloxan + Ekstrak 750 mg/kgBB/hari (P3) & 120 & 116 & 105 & 113,67 & 7,77 \\
\hline 6 & Aloxan + Metformin 500 mg/kgBB/hari (P4) & 176 & 158 & 167 & 167 & 9 \\
\hline
\end{tabular}

Berdasarkan tabel diatas dapat dilihat bahwa mencit pada kelompok kontrol negatif (KN) menunjukan kadar gula darah yang rendah dibandingkan kelompok lainnya. Hal ini dikarenakan mencit kelompok kontrol tidak mengalami hiperglikemia akibat induksi aloksa. Sebalikanya pada kelompok kontrol positif (KP) yang diinduksi aloksan 125 $\mathrm{mg} / \mathrm{kgBB}$ memperlihatkan kadar gula darah yang tinggi (hiperglikemia).

Pengaruh pemberian ekstrak terhadap penurunan kadar gula darah dapat dilakukan dengan membandingkan setiap kelompok perlakuan dengan kelompok konrol positif sehingga dapat dihitung persentase penurunan kadar gula darah setiap kelompok perlakuan. Diagram di bawah ini memperlihatkan pengaruh positif pemberian ekstrak daun paitan terhadap penurunan kadar gula darah mencit.

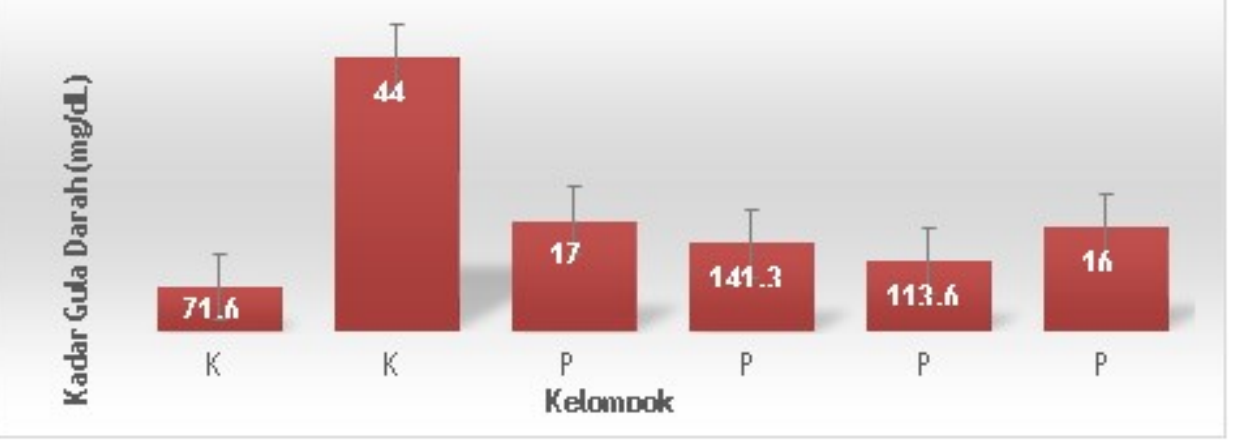

Gambar 2. Pengaruh Pemberian Ekstrak Daun Paitan Terhadap Penurunan Kadar Gula Darah Mencit

Kelompok P1 dengan kadar ekstrak daun paitan $250 \mathrm{mg} / \mathrm{kgBB} / \mathrm{hari}$ mengalami penurunan kadar gula darah sebesar $179 \mathrm{mg} / \mathrm{dL}$ atau 33,87\% dibandingkan kelompok kontrol positif. Pada kelompok P2 dengan kadar ekstrak daun paitan $500 \mathrm{mg} / \mathrm{kgBB} / \mathrm{hari}$ penurunan kadar gula darah yang terjadi lebih baik dibandingkan dengan kelompok yang diberi metformin, yaitu sebesar $141,33 \mathrm{mg} / \mathrm{dL}$ atau $62,90 \%$ ). Kelompok yang memberikan penurunan kadar gula darah terendah dibandingkan dengan kelompok metformin adalah kelompok P3. Dengan kandungan ekstrak daun paitan sebesar 750 $\mathrm{mg} / \mathrm{kgBB} /$ hari memberikan penurunan kadar gula darah sebesar $113,67 \mathrm{mg} / \mathrm{dL}$ atau $71,13 \%$.

Penurunan kadar gula darah yang disebabkan oleh pemberian ekstrak daun paitan, diduga kuat karena kandungan flavonoid dan seskuiterpennya ${ }^{21}$. Flavonoid memiliki aktifitas antioksidan. Flavonoid diduga berperan secara signifikan dalam regenerasi sel $\beta$-pankreas yang rusak sehingga defisiensi insulin dapat diatasi ${ }^{22}$. Reactive Oxygen 
species (ROS) sebagai sumber stres oksidatif pada penderita DM terjadi akibat adanya perubahan metabolisme karbohidrat dan lemak. Pemberian antioksidan dapat mengikat radikal bebas sehingga dapat mengurangi resistensi insulin ${ }^{18}$. Menurut Winarsi, 2012, senyawa flavonoid mampu menstimulasi penggunaan glukosa perifer dengan cara meningkatkan jalur glikolitik dan glikogenik sehingga proses glikogenolisis dan glukoneogenesis dapat ditekan ${ }^{20}$. Flavonoid juga merupakn senyawa inhibitor yang kuat terdadap $\alpha$ - amilase yang berfungsi dalam proses pemecahan karbohidrat ${ }^{23}$. Penelitian yang dilakukan oleh Fitmawati dan dan sofiyanti, 2014, memperlihatkan kandungan asam tanat yang tinggi yaitu $60,16 \mathrm{mg} / \mathrm{g}$ ekstrak $^{14}$. Asam tanat dapat meningkatkan glikogenesis sehingga mampu menurunkan kadar gula darah. Senyawa lainnya yang terdapat dalam T. diversifolia adalah seskuiterpen. Seskuiterpen secara signifikan mampu meningkatkan metabolisme glukosa tanpa efek toksik pada sel adiposit, juga memiliki daya hambat terhadap a-glikosidase. Seskuiterpen juga memiliki daya hambat terhadap ekspresi induksi glukosa pada inflamasi sitokiin pada sel mesangial manusia.

\section{Kesimpulan}

Berdasarkan penelitian yang dilakukan terhadap mencit yang diinduksi aloksan dapat disimpulkan bahwa daun paitan (Tithonia diversifolia, $\mathrm{H}$ ) dapat menurunkan kadar gula darah mencit yang diinduksi aloksan. Ekstrak daun paitan dosis $500 \mathrm{mg}$ merupakan dosis yang efektif yang dapat menurunkan kadar gula darah sebaik metformin.

\section{Daftar Pustaka}

1. American Diabetes Association, 2015, Stan- dars of Medical Care in Diabetes, Diabetes Care, 38, 1

2. Finkelstein, E. A., Chay, J., dan Bajpai, S., 2014, The Economic Burden of SelfReported and Undiagnosed Cardio- vacular Diseases and Diabetes on Indonesia Households. PLoS ONE, Vol. 9, No.6 : 1-3.

3. Abbas A. K, Maitra A. The endocrine sys- tem. In: Kumar V, Abbas A., Nelson F., Robbins and Cotran., 2005, Pathologics basis of disease.7th ed.Philadelphia, USA: Elsevier Saunders, $1155-224$

4. Dipiro, T .J., R. L., Talbert, G.C., Yee, G. R., R., Matzke, B .G., Welss, L. M., dan Possey. 2014 : Pharmacotherapy: A Patho-physiologic Approach, $9^{\text {th }}$ Ed., McGraw Hill Company, United States of America

5. Chon, H., Peng, L. Y., Jiang, B., Hon, A. J., Lia, Z.W. and Sun, H.D. 2000. Chemical constituent from Tithonia diversi- folia. Yannan Zhiwu Yanjiu, 22 pp.361364

6. Wild, S., Roglic, G., Green, A., Sicree, R.and king, 2004. Global prevalence of Diabetes : estimates for the year 2000 and projections for 2030. Diabetic Care, 27 pp.1047-1053

7. Ruhe, R. C. and McDonald, R. B. 2001. Use Of antioxidant nutrient in the prevention and treatment of type 2 diabetes. J.Am.Coll. Nutr., 20(5) pp.363-369

8. Depkes RI. 2014. Situasi dan Analisis Diabe- tes. Jakarta: InfoDATIN, Pusat Data dan Informasi Kementerian Kesehatan RI Dalimartha, S. 2005. Tanaman Obat di Lingkungan Sekitar.Jakarta: Penerbit Puspa Swara.

9. Nugroho B. A., Puwaningsih E. Perbedaan diet ekstrak rumput laut (Euchema Sp) dan insulin dalam menurunkan kadar glukosa darah tiku putih (Rattus norvegicus) hiperglikemik. Media Medika Indonesia Vol.41 No. 1, 2006 : 23-30 
10. Suyono S, Purnamasari D, Soegondo S. Diabetes mellitus di Indonesia, diagnosis dan klasifikasi diabetes mell- itus, farmakoterapi pada pengendalian glikemia diabetes mellitus tipe 2. Dalam: Sudoyo AD, Setiyohadi B, Alwi I, Simadibrata M, Setiati S, editor. Buku ajar ilmu penyakit dalam. Edisi ke- 5(III). Jakarta: Pusat Penerbitan IImu Penyakit Dalam; 2009. 3.

11. Yulianty, O., Sudiastuti, and Nugroho, R. A. 2015.Efek Ekstrak Biji Ketumbar (Coriandrum sativum L.) terhadap Histologi PankreasMencit (Mus musculus L.) Diabetik Aloksan. Prosiding Seminar Tugas Akhir FMIPA UNMUL 2015 Periode Juni 2015, Samarinda.

12. Okayasu S, Kitaichi K, Hori A, Suwa T, Horikawa Y, Yamamoto M, et al. The evaluation of risk factors associated with adverse drug reactions by metformin in type 2 diabetes mellitus. Biol Pharm Bull. 2012; 35(6):933-7. doi: $10.1248 /$ bpb. 35.933

13. American Diabetes Association, 2010, Diag- nosis and classification of diabetes melitus. Diabetes Care. 33(1) : S62- S69. doi: 10.2337/dc10-S062 2.

14. Fitmawati T., Sofiyanti, N., Identifikasi Tumbuhan Antidiabetes Berdasarkan Analisis Kuanti- atif Asam Tanat, 2014, JOM FMIPA, Vol I, Bina Widya, Pekanbaru

15. Jamal, Y. and Agusta, A. 1999. Komponen Kimia Dan Uji Daya Antibakteri Ekstrak Daun Kirinyu (Tithonia diver- sifolia). Bogor: Laboratorium Treub, Puslitbang Bioogi-LIPI.

16. Lacy C F, Armstrong L L, Goldman M P, Lanco LL. Drug information handbook: metformin. Edisi ke-17. Ohio: Lexi Comp Inc; 2007

17. Flint A, Arslanian S.,2011, Treatment of type 2 diabetes in youth. Diabetes Care, 34 (Suppl 2): S177-83. doi: 10.2337/ dc11- s215 5.

18. Rosiyana AN. 2012. Skripsi Aktivitas Antioksidan dan Penghambatan $\alpha$ Glukosidase Ekstrak dan Nano-partikel Ekstrak Kulit Kayu Mahoni (Swietenia macrophylla K), IPB

19. Katz L.L., Abraham M., 2006, Dominant Western health care: type 2 diabetes mellitus. Transcult Nurs. 17(3):230-3. doi: 10.1177/1043659606288377

20. Winarsi, H., Sasongko, N.D., Purwanto, A.,Arinton, I.G. and Nuraeni, I. 2012. In vitro antioxidant activity of the stem andleaves Amomum cardamomum extracts International Conference on Medicinal Plants. Purwokerto, 11-13 October.

21. Bouchoucha M, Uzzan B, Cohen R., 2011, Metformin and digestive disorders. Diabetes Metab,37(2) : 90-6. doi: 10.1016/j.diabet.2010.11.002

22. Abdelmoaty, M. A., Ibrahim, M. A., Ahmed, N. S., and Abdelaziz, M. A. 2010. Confirmatory Studies on the Anti- oxidant and Antidiabetic Effect of Quercetin inRats. Indian Journal of ClinicalBiochemistry, 25(2) pp.188-192

23. Zhao, G., Li, X., Chen, W., Xi, Z., and Sun, L.2012. Three new sesquiterpenes from Tithonia diversifolia and their antihyperglycemic activity. Fitoterapia, $83 \mathrm{pp}$. $1590-1597$. 